\title{
Nitrogen availability prevents oxidative effects of salinity on wheat growth and photosynthesis by up-regulating the antioxidants and osmolytes metabolism, and secondary metabolite accumulation
}

Mohammad Abass Ahanger ${ }^{1}$, Cheng Qin ${ }^{1}$, Naheeda Begum ${ }^{1}$, Qi Maodong ${ }^{1}$, Xu Xue Dong ${ }^{1}$, Mohamed El-Esawi ${ }^{2,3}$, Mohamed A. El-Sheikh ${ }^{4,5}$, Abdulrahman A. Alatar ${ }^{4}$ and Lixin Zhang ${ }^{1 *}$

\begin{abstract}
Background: Salinity is one of the damaging abiotic stress factor. Proper management techniques have been proposed to considerably lower the intensity of salinity on crop growth and productivity. Therefore experiments were conducted to assess the role of improved nitrogen $(\mathrm{N})$ supplementation on the growth and salinity stress tolerance in wheat by analyzing the antioxidants, osmolytes and secondary metabolites.

Results: Salinity (100 mM NaCl) stress imparted deleterious effects on the chlorophyll and carotenoid synthesis as well as the photosynthetic efficiency. $\mathrm{N}$ supplementation resulted in increased photosynthetic rate, stomatal conductance and internal $\mathrm{CO}_{2}$ concentration with effects being much obvious in seedlings treated with higher $\mathrm{N}$ dose. Under non-saline conditions at both $\mathrm{N}$ levels, protease and lipoxygenase activity reduced significantly reflecting in reduced oxidative damage. Such effects were accompanied by reduced generation of toxic radicals like hydrogen peroxide and superoxide, and lipid peroxidation in N supplemented seedlings. Antioxidant defence system was up-regulated under saline and non-saline growth conditions due to $\mathrm{N}$ supplementation leading to protection of major cellular processes like photosynthesis, membrane structure and function, and mineral assimilation. Increased osmolyte and secondary metabolite accumulation, and redox components in N supplemented plants regulated the ROS metabolism and $\mathrm{NaCl}$ tolerance by further strengthening the antioxidant mechanisms.

Conclusions: Findings of present study suggest that $\mathrm{N}$ availability regulated the salinity tolerance by reducing $\mathrm{Na}$ uptake and strengthening the key tolerance mechanisms.
\end{abstract}

Keywords: Nitrogen, Antioxidants, AsA-GSH cycle, Oxidative damage, Salinity, Triticum aestivum

\footnotetext{
* Correspondence: zhanglixin@nwafu.edu.cn

${ }^{1}$ College of Life Sciences, Northwest A\&F University, Yangling, Shaanxi, China

Full list of author information is available at the end of the article
}

(c) The Author(s). 2019 Open Access This article is distributed under the terms of the Creative Commons Attribution 4.0 International License (http://creativecommons.org/licenses/by/4.0/), which permits unrestricted use, distribution, and reproduction in any medium, provided you give appropriate credit to the original author(s) and the source, provide a link to the Creative Commons license, and indicate if changes were made. The Creative Commons Public Domain Dedication waiver (http://creativecommons.org/publicdomain/zero/1.0/) applies to the data made available in this article, unless otherwise stated. 


\section{Background}

Plants are continuously confronted by variety of environmental stresses resulting in significant growth retardation and yield reduction. Salinity stress is considered as one of the damaging abiotic stress factor affecting metabolism and productivity of crop plants allover the globe $[1,2]$. Increasing salinity has been considered as global threat to food security causing significant conversion of agricultural arable land into unproductive waste land. Salinity affects mineral uptake and assimilation, enzyme activity, photosynthesis, protein expression and hormone metabolism [2, 3]. Excess salt concentrations in growth medium induces osmotic and ionic stress resulting in occurrence of obvious growth changes including reduced leaf area, necrosis and abscission $[4,5]$. Tolerance to salinity is a complex trait involving several physiological, biochemical, molecular and gene networks [6]. Salinity disturbs the ionic balance resulting in reduction of water content, and oxidative damage due to accumulation of excess reactive oxygen species (ROS) leading to peroxidation of lipids $[3,7]$. It is essential to identify the physio-biochemical and molecular attributes for enhancing the salinity tolerance [6]. Salinity stress has been reported to affect the uptake and metabolism of essential elements like N, P, K, S and Ca leading to significant alterations in the photosynthetic efficiency and the tolerance mechanisms involved [1,7]. Among the most deleterious products of saline environment are included the ROS like superoxide, hydrogen peroxide, peroxide and hydroxyl radical $[1,8]$. To avoid the salinity mediated growth restrictions plants up-regulate certain indigenously occurring tolerance mechanisms like antioxidant system, osmolyte and secondary metabolite accumulation $[6,9]$. Salinity induced increase in ROS results in oxidative damage to important molecules including proteins, lipids, nucleic acids etc. Increased ROS accumulation hampers redox homeostasis declining the photosynthetic efficiency [7], and nutrient and osmolyte metabolism [1]. For assuaging the salinity mediated ROS-induced deleterious effects on growth the antioxidant system and osmoregulatory components are up-regulated [2]. In addition to this salt exclusion at root and vacuole level is considered as an important key mechanism regulating tolerance in plants $[10,11]$. It has been reported that plants displaying greater antioxidant and osmolyte metabolism in addition of the selective accumulation of mineral ions exhibit increased tolerance to salinity $[2,7]$. Every cellular compartment has its own set of ROSproducing and -neutralising pathways for maintaining the steady-state levels of ROS and the redox state, thereby giving rise to distinct ROS signatures in different cellular compartments $[1,8,12]$. It is believed that different ROS signatures determine the stress acclimation specificity by mediating systemic signalling. Antioxidant system is constituted of both enzymatic and non-enzymatic components $[12,13]$. Compatible osmolytes like proline, glycine betaine and sugars assist the antioxidant system in neutralising the excess ROS. Osmolytes act as nutrient and metabolite signalling molecules activating specific or hormone crosstalk transduction pathways and modify gene expression and proteomic patterns [13]. Nitrogen $(\mathrm{N})$, a macroelement which is actively involved in regulation of enzyme activity, photosynthesis, protein synthesis, antioxidant and osmolyte metabolism [14-16]. $\mathrm{N}$ forms the component of major molecules including nucleic acids, proteins, chlorophylls etc. and its deficient availability results in oxidative damage to membranes, photosynthetic inhibition and impeded nutrient uptake $[17,18] . \mathrm{N}$ availability regulates the synthesis of hormones, osmolytes [16, 19], secondary metabolites [20] and the activity of antioxidant system [15]. Earlier Ahanger and Agarwal [1, 21] have reported that upregulated antioxidant and osmolyte metabolism prevents salinity and water stress mediated growth inhibition by protecting nitrogen and secondary metabolite metabolism. However, the role of $\mathrm{N}$ availability in regulation of antioxidant, osmolyte and secondary metabolism under salinity stress remains to be least researched area. It is with this backdrop we hypothesized that (a) whether $\mathrm{N}$ supplementation modulates antioxidant, osmolyte and secondary metabolite metabolism for enhancing the salinity tolerance, and (b) the effectivity of improved $\mathrm{N}$ supplementation in the alleviation of salinity mediated changes in growth and physio-biochemical attributes.

\section{Results}

\section{$\mathrm{N}$ supplementation reduced $\mathrm{Na}$ accumulation and improved $\mathrm{K}$ uptake}

Results regarding the effect of $\mathrm{N}$ availability on the uptake of $\mathrm{Na}$ and $\mathrm{K}$ are shown in Table 1 . Relative to control, accumulation of $\mathrm{Na}$ increased by $56.94 \%$ due to $\mathrm{NaCl}$ treatment which was declined by 40.36 and $56.15 \%$ due to supplementation of $\mathrm{N}$ at 50 and $100 \mathrm{mg} \mathrm{kg}^{-1}$ soil (N1 and N2) respectively over the $\mathrm{NaCl}$ stressed counterparts. Under normal conditions, supplementation of $\mathrm{N}$ significantly reduced $\mathrm{Na}$ accumulation with maximal decline of $65.05 \%$ observed with $100 \mathrm{mg} \mathrm{kg}^{-1}$ (N2). K uptake was significantly improved by increasing $\mathrm{N}$ supplementation attaining maximal increase of $32.74 \%$ with N2. Nitrogen supplementation proved beneficial in reducing the $\mathrm{NaCl}$ mediated decline in $\mathrm{K}$ with percent amelioration of 18.50 and $34.63 \%$ at $\mathrm{N} 1$ and $\mathrm{N} 2$ respectively over the $\mathrm{NaCl}$ stressed plants (Table 1 ).

Pigment synthesis and photosynthesis improved due to $\mathrm{N}$ supplementation under $\mathrm{NaCl}$ stress

Salinity stress reduced the synthesis of chlorophyll and carotenoid pigments resulting in declined photosynthetic rate. Total chlorophyll, carotenoids, photosynthetic rate, stomatal conductance, intercellular $\mathrm{CO}_{2}$ concentration and transpiration rate was observed to increase with $\mathrm{N}$ 
Table 1 Effect of nitrogen supplementation on the uptake of sodium, potassium, nitrogen and nitrate reductase activity in Triticum aestivum $L$ subjected to salinity stress. Data is mean $( \pm S E)$ of three replicates. Values followed by different letters are significantly different at $P<0.05$

\begin{tabular}{lllllll}
\hline & Control & $\mathrm{NaCl}$ & $\mathrm{N} 1$ & $\mathrm{~N} 2$ & $\mathrm{NaCl}+\mathrm{N} 1$ & $\mathrm{NaCl}+\mathrm{N} 2$ \\
\hline $\mathrm{Na}\left(\mathrm{mg} \mathrm{g}^{-1} \mathrm{DW}\right)$ & $5.98 \pm 0.54 \mathrm{c}$ & $13.89 \pm 0.92 \mathrm{a}$ & $3.40 \pm 0.17 \mathrm{~d}$ & $2.09 \pm 0.15 \mathrm{de}$ & $9.90 \pm 0.81 \mathrm{~b}$ & $6.09 \pm 0.59 \mathrm{c}$ \\
$\mathrm{K}\left(\mathrm{mg} \mathrm{g}^{-1} \mathrm{DW}\right)$ & $22.78 \pm 1.8 \mathrm{c}$ & $13.87 \pm 1.01 \mathrm{e}$ & $26.09 \pm 2.1 \mathrm{~b}$ & $33.87 \pm 2.4 \mathrm{a}$ & $17.02 \pm 1.12 \mathrm{~d}$ & $21.22 \pm 1.9 \mathrm{c}$ \\
\hline
\end{tabular}

supplementation reaching to maximal increase of 38.71, $32.08,51.47,33.71,29.37$ and $33.47 \%$ over the control plants with N2. Maximal amelioration of salinity mediated decline was observed with $\mathrm{N} 2$ with $47.36 \%$ for total chlorophyll, $56.39 \%$ for carotenoids, $54.31 \%$ for photosynthetic rate, $30.91 \%$ for stomatal conductance, $33.64 \%$ for intercellular $\mathrm{CO}_{2}$ concentration and $42.81 \%$ for transpiration rate over the $\mathrm{NaCl}$ stressed plants (Table 2).

\section{$\mathrm{N}$ availability induces synthesis of osmolytes under salinity stress}

Proline, free amino acids, glycine betaine and sugars increased due to supplementation of $\mathrm{N}$ and maximal accumulation was observed with higher $\mathrm{N}$ dose. Relative to control, proline, free amino acids, glycine betaine and sugars increased by $34.07,44.72,46.57$ and $34.52 \%$ due to supplementation of $50 \mathrm{~N}$ and by $44.95,54.87,54.52$ and $58.61 \%$ due to $100 \mathrm{~N}$. Maximal percent increase of 49.61\% for proline, $62.50 \%$ for free amino acids, $64.03 \%$ for glycine betaine and $63.19 \%$ for sugars was observed in $\mathrm{NaCl}+100 \mathrm{~N}$ over the control (Fig. 1) and these values were much higher than the $\mathrm{NaCl}$ stressed ones.

\section{Increased $\mathrm{N}$ application reduced oxidative stress}

Seedlings exposed to salinity exhibited increased generation of free radicals like $\mathrm{H}_{2} \mathrm{O}_{2}$ and $\mathrm{O}_{2}{ }^{-}$over the control and $\mathrm{N}$ supplemented ones. Percent increase in $\mathrm{H}_{2} \mathrm{O}_{2}$ and $\mathrm{O}_{2}{ }^{-}$due to $\mathrm{NaCl}$ was 62.11 and $63.78 \%$ respectively causing $44.60 \%$ increase in lipid peroxidation over the control. Relative to control, N supplementation significantly declined the generation of $\mathrm{H}_{2} \mathrm{O}_{2}$ (2.5 fold) and $\mathrm{O}_{2}{ }^{-}$(1.7 fold) causing $62.01 \%$ decline in lipid peroxidation. Supplementation of N2 to $\mathrm{NaCl}$ stressed plants maximally ameliorated the generation of $\mathrm{H}_{2} \mathrm{O}_{2}$ and $\mathrm{O}_{2}{ }^{-}$resulting in $33.42 \%$ decline in lipid peroxidation as compared to $\mathrm{NaCl}$ stressed ones (Fig. 2a-c). $\mathrm{N}$ fed seedlings showed apparent decline in the activities of protease and lipoxygenase over the control as well as $\mathrm{NaCl}$ stressed ones with maximal decline observed with higher N. Relative to control, protease and lypoxygenase increased by 1.73 and 2.17 folds in $\mathrm{NaCl}$ stressed plants, however supplementation of $\mathrm{N}$ maintained the effect even under $\mathrm{NaCl}$ conditions. At $100 \mathrm{~N}$ (N2), protease and lypoxygenase decreased by 52.00 and $51.97 \%$ respectively, and $\mathrm{NaCl}+\mathrm{N} 2$ treated plants exhibited a decline of 36.54 and $40.72 \%$ over the $\mathrm{NaCl}$ stressed counterparts (Fig. 3a-b).

\section{$\mathrm{N}$ supplementation up-regulates the antioxidant system}

Results revealed that availability of $\mathrm{N}$ significantly affected the antioxidant system by up-regulating the activity of SOD, CAT, APX, GR, MDHAR, DHAR and the synthesis of AsA and GSH. Relative to control, under normal conditions maximal increase in SOD (1.96 fold), CAT (1.52 fold), APX (2.28 fold), GR (2.16 fold), MDHAR (1.71 fold), DHAR (1.73 fold), AsA (1.47 fold), and GSH (1.46 fold) was observed with $100 \mathrm{~N}$ (N2). Though $\mathrm{NaCl}$ stress triggered the activity of antioxidant enzymes however, $\mathrm{N}$ supplemented seedlings exhibited maximal activity with increase of 2.27 fold for SOD, 1.76 fold for CAT, 2.89 fold for APX, 2.39 fold for GR, 2.10 fold for MDHAR, 1.93 fold for DHAR and 1.61 fold for $\mathrm{GSH}$ in $\mathrm{NaCl}+\mathrm{N} 2$ treated seedlings (Figs. 4 and 5). Tocopherol content also exhibited apparent increase with $\mathrm{N}$ supplementation. Relative to control, tocopherol increased by 50.27 and $65.17 \%$ due to $\mathrm{N} 1$ and N2 supplementation respectively. Applied N (N100) maintained

Table 2 Effect of nitrogen supplementation on the total chlorophyll, carotenoids and gas exchange parameters in Triticum aestivum $\mathrm{L}$ subjected to salinity stress. Data is mean $( \pm \mathrm{SE})$ of three replicates. Values followed by different letters are significantly different at $P<0.05$

\begin{tabular}{lllllll}
\hline & Control & $\mathrm{NaCl}$ & $\mathrm{N} 1$ & $\mathrm{~N} 2$ & $\mathrm{NaCl}+\mathrm{N} 1$ & $\mathrm{NaCl}+\mathrm{N} 2$ \\
\hline Total Chlorophyll $\left(\mathrm{mg} \mathrm{g}^{-1} \mathrm{FW}\right)$ & $1.621 \pm 0.045 \mathrm{c}$ & $0.9105 \pm 0.016 \mathrm{e}$ & $2.134 \pm 0.131 \mathrm{~b}$ & $2.645 \pm 0.142 \mathrm{a}$ & $1.326 \pm 0.0532 \mathrm{~d}$ & $1.730 \pm 0.050 \mathrm{c}$ \\
Carotenoids $\left(\mathrm{mg} \mathrm{g}^{-1} \mathrm{FW}\right)$ & $0.4620 \pm 0.011 \mathrm{c}$ & $0.3011 \pm 0.010 \mathrm{e}$ & $0.5123 \pm 0.013 \mathrm{~b}$ & $0.6803 \pm 0.012 \mathrm{a}$ & $0.3982 \pm 0.011 \mathrm{~d}$ & $0.4709 \pm 0.014 \mathrm{c}$ \\
Photosynthetic rate $\left(\mu \mathrm{mol} \mathrm{CO} \mathrm{m}^{-2} \mathrm{~s}^{-1}\right)$ & $11.81 \pm 0.54 \mathrm{~d}$ & $7.73 \pm 0.51 \mathrm{e}$ & $17.21 \pm 1.01 \mathrm{~b}$ & $24.34 \pm 1.21 \mathrm{a}$ & $13.33 \pm 0.45 \mathrm{c}$ & $16.92 \pm 1.001 \mathrm{~b}$ \\
Net intercellular $\mathrm{CO}_{2}\left(\mu \mathrm{mol} \mathrm{m} \mathrm{s}^{-1}\right)$ & $226.1 \pm 7.12 \mathrm{~d}$ & $176.1 \pm 6.15 \mathrm{e}$ & $298.3 \pm 9.15 \mathrm{~b}$ & $341.1 \pm 9.98 \mathrm{a}$ & $222.9 \pm 6.99 \mathrm{~d}$ & $254.9 \pm 8.012 \mathrm{c}$ \\
Stomatal conductance $\left(\mathrm{mmol} \mathrm{m}^{-2} \mathrm{~s}^{-1}\right)$ & $312.1 \pm 8.52 \mathrm{~d}$ & $246.3 \pm 7.01 \mathrm{e}$ & $398.1 \pm 10.21 \mathrm{~b}$ & $441.9 \pm 15.01 \mathrm{a}$ & $314.6 \pm 8.11 \mathrm{~d}$ & $371.2 \pm 9.77 \mathrm{bc}$ \\
Transpiration rate $\left(\mathrm{mmol} \mathrm{H}_{2} \mathrm{O} \mathrm{m}^{-2} \mathrm{~s}^{-1}\right)$ & $3.14 \pm 0.10 \mathrm{c}$ & $1.72 \pm 0.011 \mathrm{e}$ & $4.14 \pm 0.14 \mathrm{~b}$ & $4.72 \pm 0.13 \mathrm{a}$ & $2.33 \pm 0.031 \mathrm{~d}$ & $3.008 \pm 0.21 \mathrm{c}$ \\
\hline
\end{tabular}




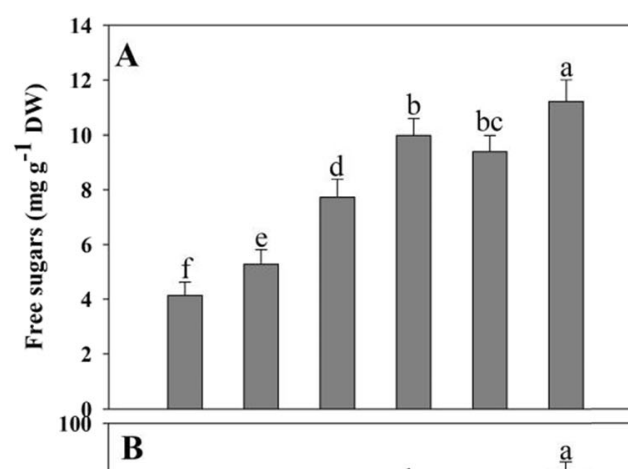

Fig. 1 Effect of nitrogen (50 and $100 \mathrm{mg} \mathrm{kg}^{-1}$ soil) supplementation on the content of (a) free sugars, (b) free proline, (c) free amino acids, (d) glycine betaine and (e) relative water content in Triticum aestivum $\mathrm{L}$ subjected to salinity stress. Data is mean ( \pm SE) of three replicates, bars denoted by different letters are significantly different at $P<0.05$

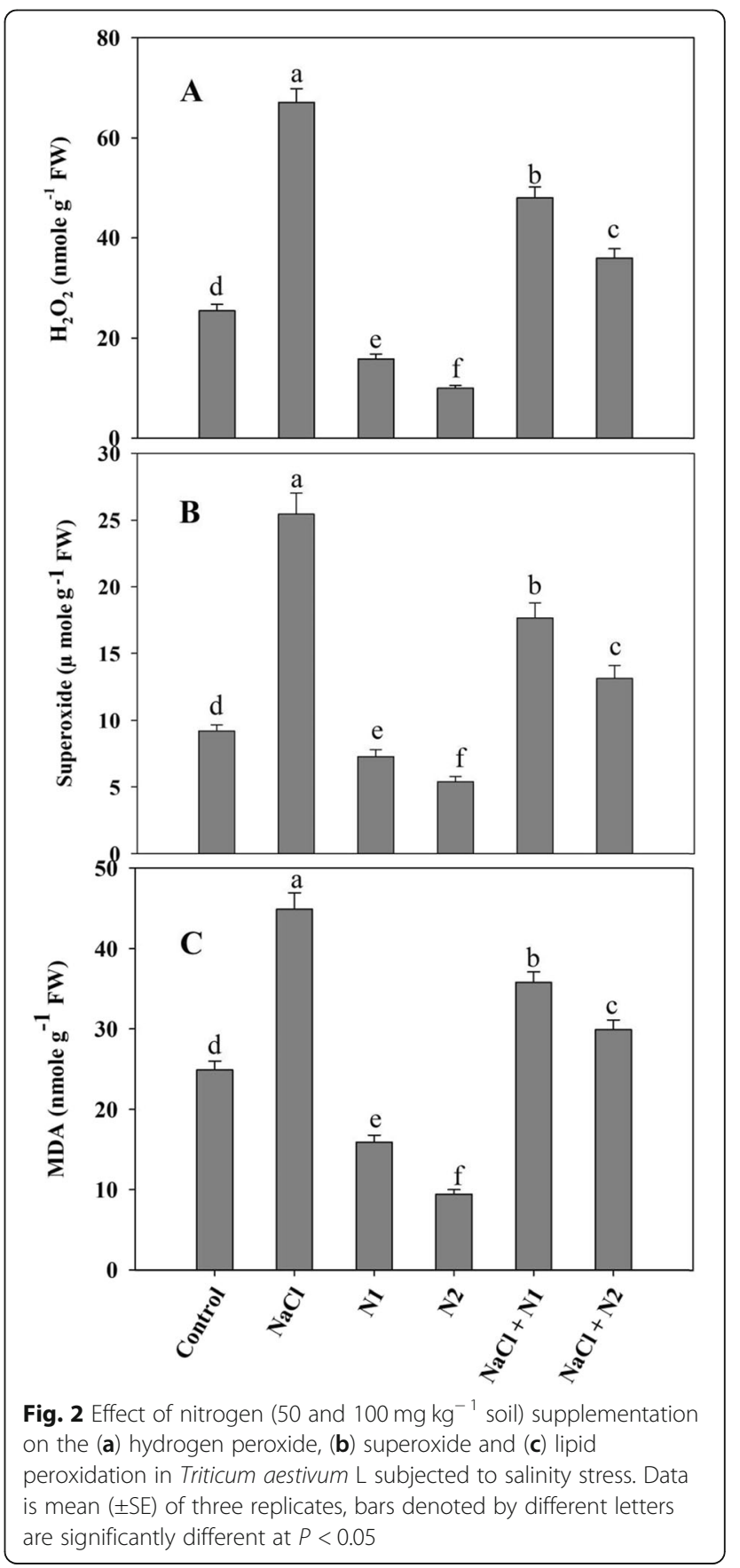




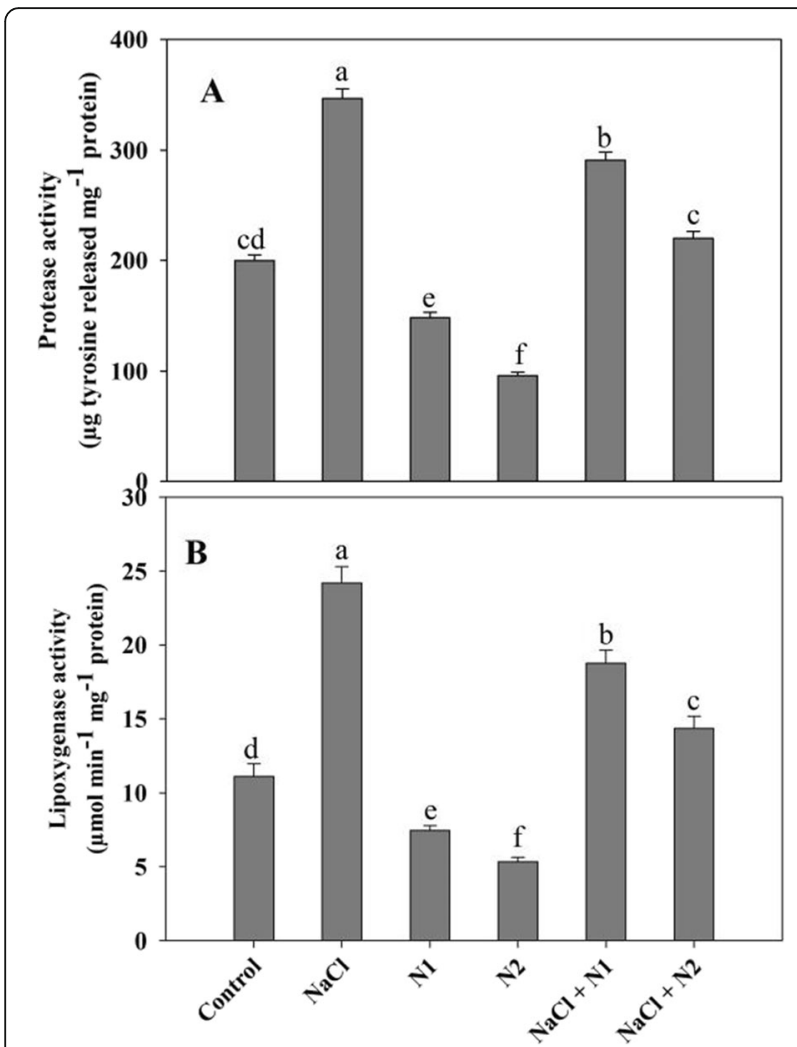

Fig. 3 Effect of nitrogen (50 and $100 \mathrm{mg} \mathrm{kg}^{-1}$ soil) supplementation on the (a) protease and (b) lipoxygenase activity in Triticum aestivum $\mathrm{L}$ subjected to salinity stress. Data is mean $( \pm \mathrm{SE})$ of three replicates, bars denoted by different letters are significantly different at $P<0.05$

its effect on the tocopherol under $\mathrm{NaCl}$ conditions leading to an enhancement of $60.99 \%$ over the $\mathrm{NaCl}$ stressed pants (Fig. 6).

\section{Phenols and flavonoids increased in $\mathrm{N}$ supplemented seedlings}

The content of phenols and flavonoids was maximum in $\mathrm{N}$ supplemented seedlings under normal as well as $\mathrm{NaCl}$ stressed conditions. Percent increase in phenol and flavonoids was 19.04 and $16.54 \%$ due to $\mathrm{NaCl}$ stress and was further increased due to application of $\mathrm{N}$ attaining maximal values with $\mathrm{NaCl}+100 \mathrm{~N}$ over control plants. Moreover $\mathrm{N}$ availability significantly affected activity of PAL imparting 1.53 and 1.86 fold increase with 50 and $100 \mathrm{~N}$ respectively, and reaching to maximum of $53.14 \%$ with $\mathrm{NaCl}+100 \mathrm{~N}$ (Fig. 7).

\section{NR activity and $\mathrm{N}$ content increased with supplementation of $\mathrm{N}$}

$\mathrm{N}$ supplementation significantly increased the activity of NR over the control plants and also ameliorated the decline caused by $\mathrm{NaCl}$. Relative to control, $\mathrm{NaCl}$ caused a decline of $54.82 \%$ for NR and $33.62 \%$ for N content. Activity of NR was enhanced by 1.30 and 1.62 fold with 50 and $100 \mathrm{~N}$

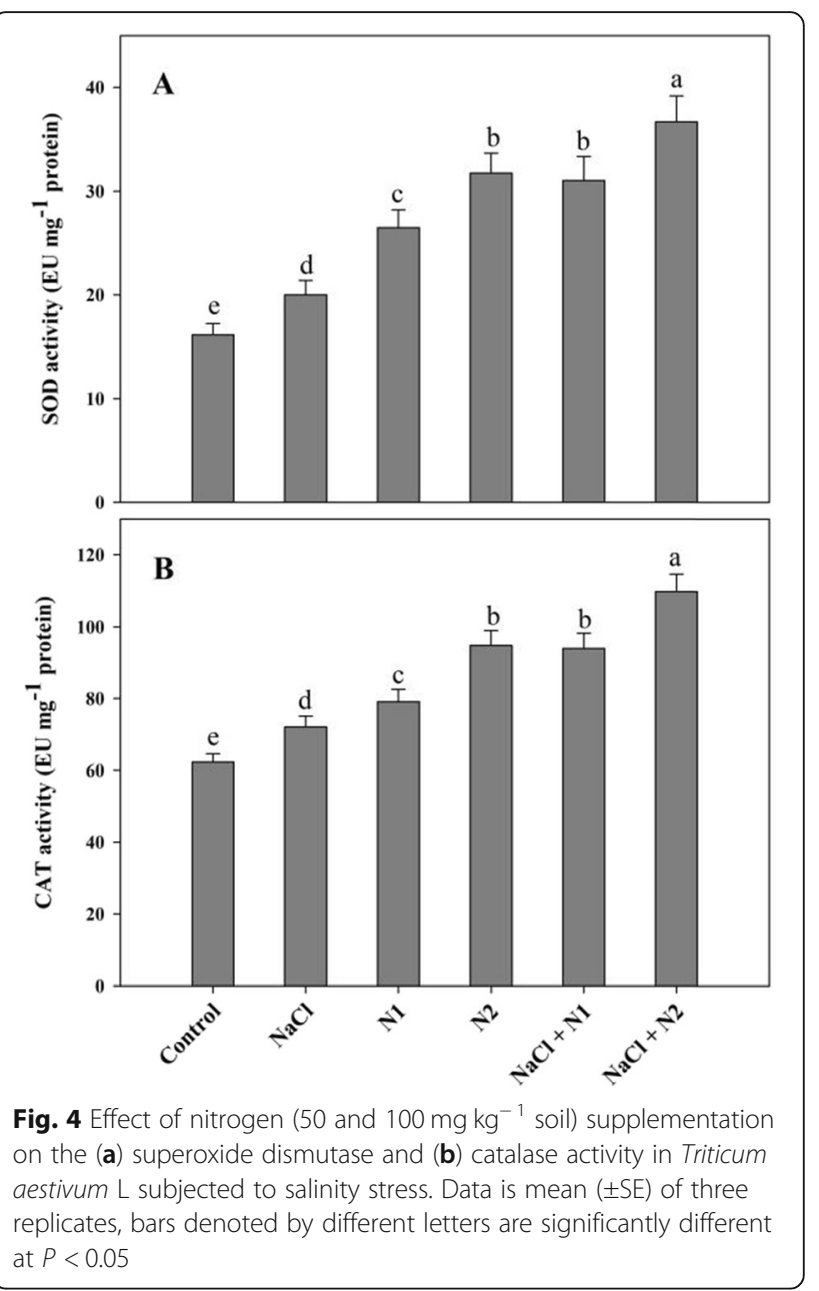

resulting in 1.49 and 1.93 fold increase leaf $\mathrm{N}$ content. Maximal amelioration of 50.15 and $46.02 \%$ in NR activity and N content was observed in $\mathrm{NaCl}+100 \mathrm{~N}$ treated seedlings over the $\mathrm{NaCl}$ stressed counterparts (Fig. 8).

\section{Discussion}

Salinity has been one of the major problems of the sustainable agricultural productivity due to its toxic effects on the metabolism of the crop plants [22]. The accumulation of $\mathrm{Na}$ and other toxic ions alter the physiological stability of plant cells leading to considerable damage to their structural and functional stability [23]. Therefore to mitigate or lessen the deleterious effects of excess $\mathrm{Na}$ plants tend to reduce the salt-induced ionic toxicity by improving the strategies aimed at improving the salt tolerance via minimizing $\mathrm{Na}^{+}$buildup in photosynthetic organs [24], improving $\mathrm{K}^{+}$levels resulting in enhanced $\mathrm{K}^{+} / \mathrm{Na}^{+}$ratio $[1,25]$. This selective ion transport leading to $\mathrm{Na}^{+}$homeostasis has been reported to be driven by several metabolic constituents like ROS [26], phytohormones [3], compatible osmolyte accumulation [1], and mineral uptake and assimilation [27]. In present study we studied the role of one of the key mineral $(\mathrm{N})$ availability on 


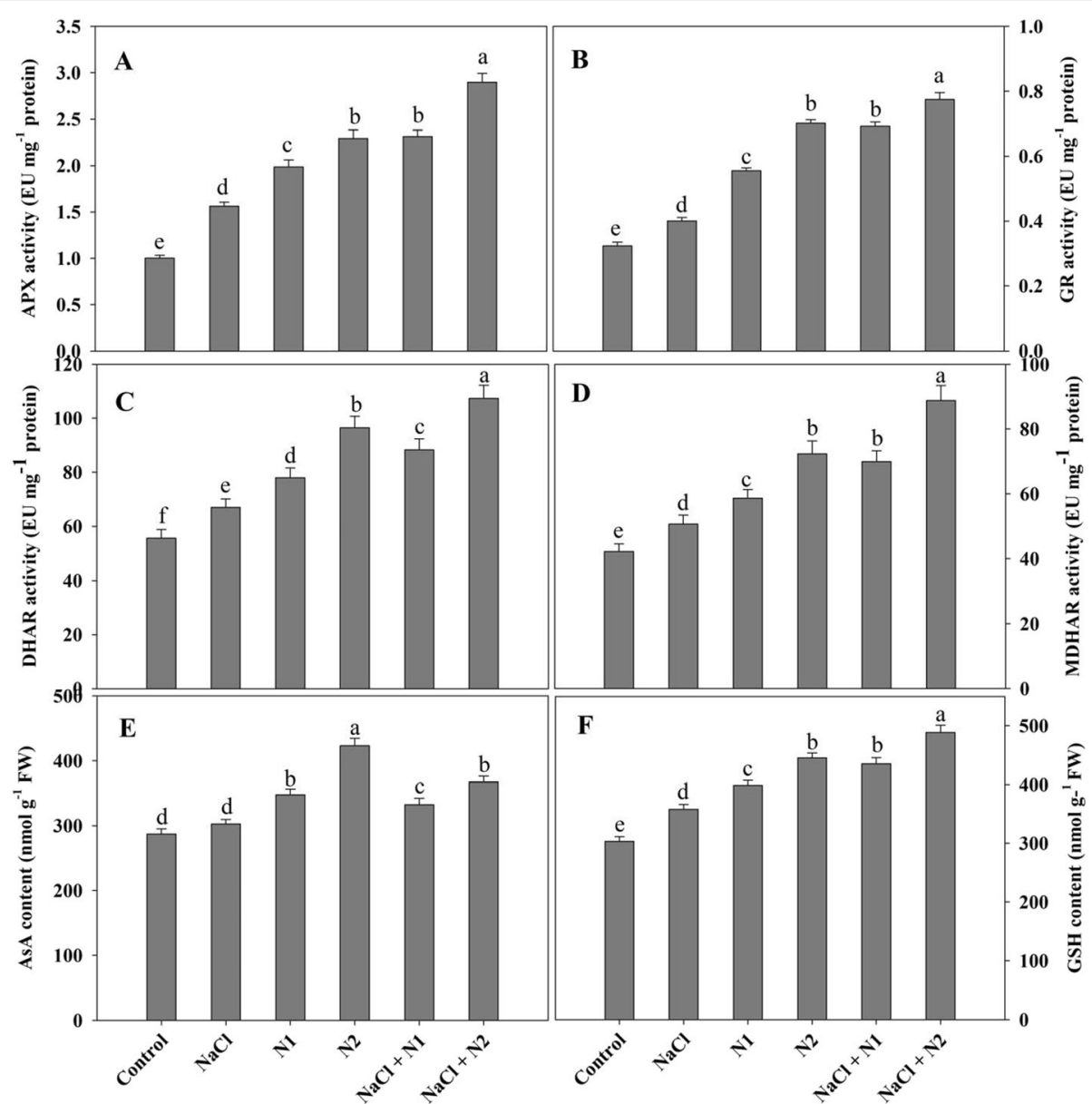

Fig. 5 Effect of nitrogen (50 and $100 \mathrm{mg} \mathrm{kg}^{-1}$ soil) supplementation on the (a) ascorbate peroxidase, (b) glutathione reductase, (c) dehydroascorbate reductase, (d) monodehydroascorbate reductase activity and content of (e) ascorbate and (f) reduced glutathione in Triticum aestivum $L$ subjected to salinity stress. Data is mean $( \pm$ SE) of three replicates, bars denoted by different letters are significantly different at $P<0.05$

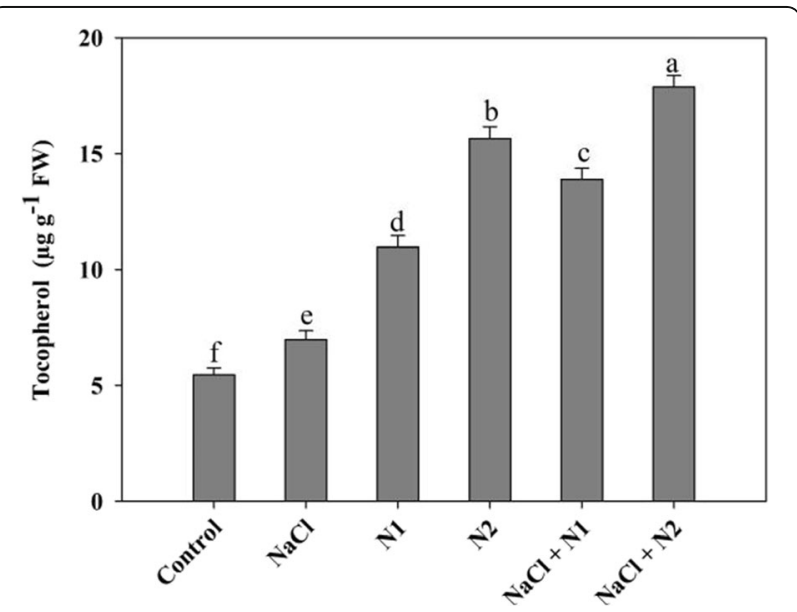

Fig. 6 Effect of nitrogen (50 and $100 \mathrm{mg} \mathrm{kg}^{-1}$ soil) supplementation on the tocopherol content in Triticum aestivum $L$ subjected to salinity stress. Data is mean $( \pm \mathrm{SE})$ of three replicates, bars denoted by different letters are significantly different at $P<0.05$ the regulation of salt tolerance through the modifications at physiological and biochemical levels. It was observed that $\mathrm{N}$ availability significantly affected the growth of wheat seedlings by restricting the uptake of $\mathrm{Na}$ with concomitant improvement in $\mathrm{K}$. $\mathrm{N}$ deficiency declines the cellular division hence reducing the cell number and tissue proliferation [28]. Juppner et al. [29] have demonstrated that accumulation of $\mathrm{N}$ containing compounds regulates the cell cycle progression, growth and biomass accumulation under the control of kinase activity. Excess $\mathrm{Na}$ is effluxed via the $\mathrm{Na} / \mathrm{H}$ exchangers (NHX) into vacuole or by SOS1 proteins at the root levels [30]. Improved activities of transport proteins involved in active compartmentation and sequestration of $\mathrm{Na}$ ions significantly contributes to salinity stress tolerance in plants [31] and in present study $\mathrm{N}$ availability mediated decline in $\mathrm{Na}$ accumulation may have resulted due to increased transport protein expression preventing $\mathrm{Na}$ uptake at root level. Increased $\mathrm{N}$ supplementation resulted in significant increase in the uptake of $\mathrm{N}$ and $\mathrm{K}$ accompanied by reduced $\mathrm{Na}$ accumulation. Earlier the ameliorative role of 


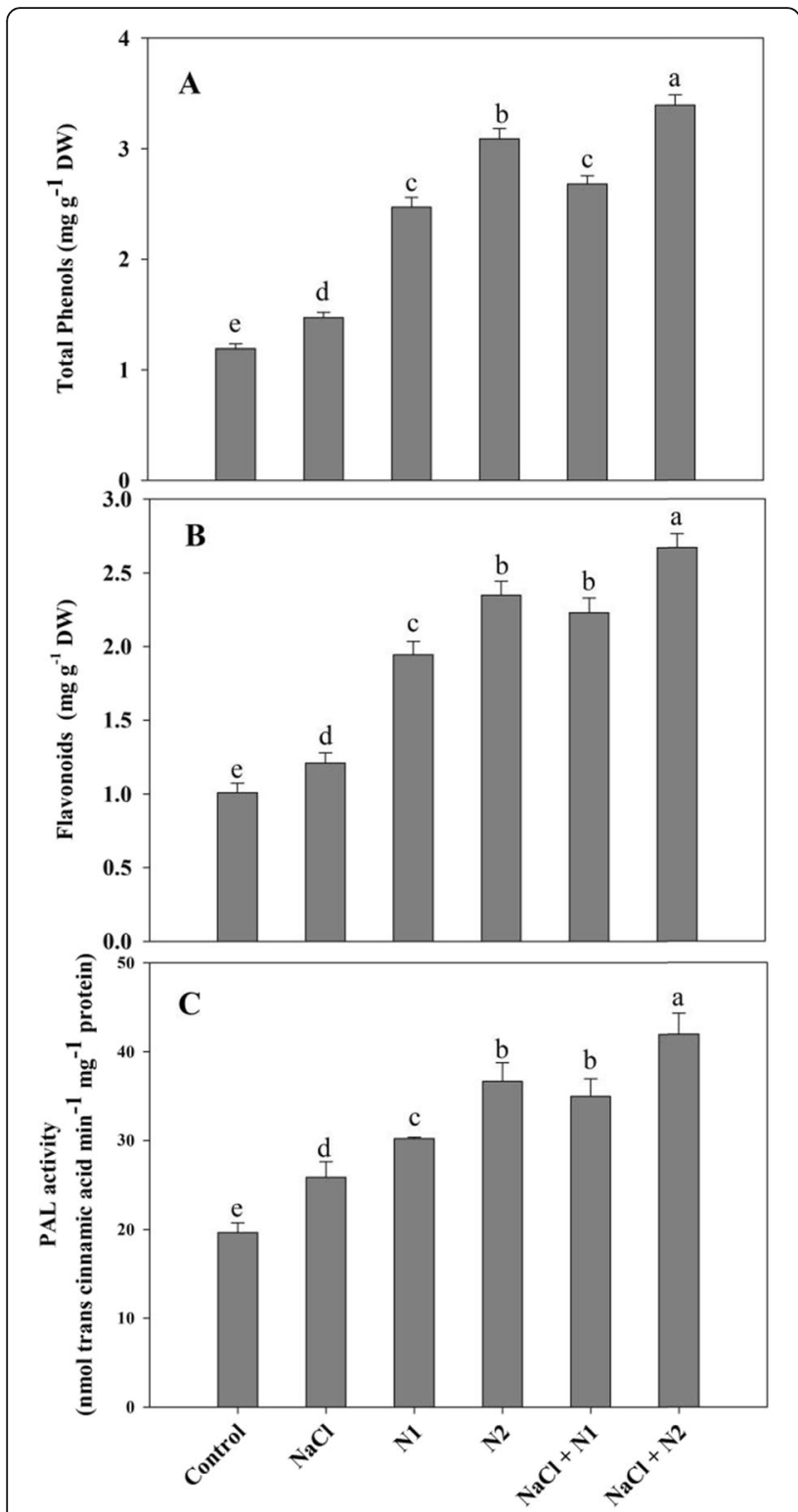

Fig. 7 Effect of nitrogen (50 and $100 \mathrm{mg} \mathrm{kg}^{-1}$ soil) supplementation on the content of (a) total phenol and (b) flavonoids, and the activity of (c) phenylalanine ammonia lyase in Triticum aestivum L subjected to salinity stress. Data is mean $( \pm \mathrm{SE})$ of three replicates, bars denoted by different letters are significantly different at $P<0.05$

increased N [19] and $\mathrm{K}$ [1] supplementation under salinity stress have been ascribed to their potentiality to prevent $\mathrm{Na}$ accumulation. $\mathrm{K}$ is ubiquitous for plant growth and development, stress mitigation, enzyme activity and osmolyte production $[1,12,21]$ and additionally $\mathrm{K}$ itself is an important inorganic osmolyte $[1,32]$. $\mathrm{N}$ supplementation improved the activity of NR facilitating its quick conversion into $\mathrm{N}$ precursors for synthesis of amino acids and hence proteins. Greater N availability directly affects the photosynthetic process by influencing the Rubisco synthesis [33]. Recently Iqbal et al. [19] have also demonstrated increased Rubisco

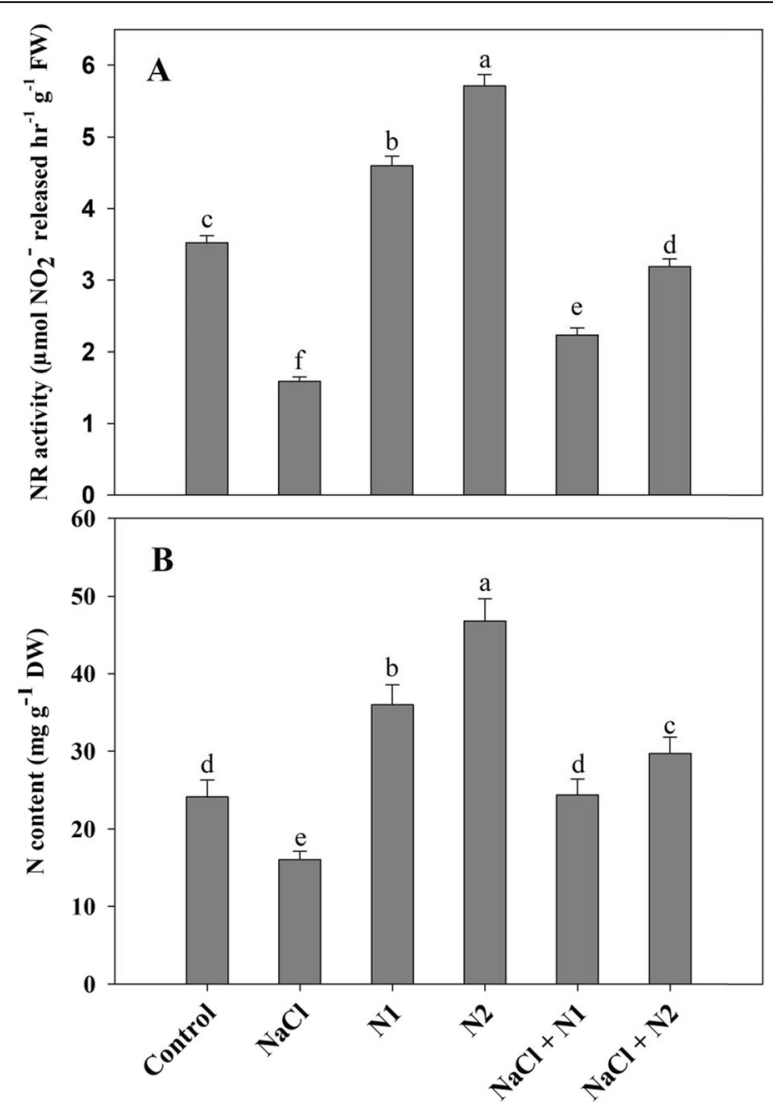

Fig. 8 Effect of nitrogen (50 and $100 \mathrm{mg} \mathrm{kg}^{-1}$ soil) supplementation on the activity of (a) nitrate reductase and (b) nitrogen content in Triticum aestivum $L$ subjected to salinity stress. Data is mean ( \pm SE) of three replicates, bars denoted by different letters are significantly different at $P<0.05$

activity in $\mathrm{N}$ supplemented seedlings causing significant amelioration of salinity mediated decline in photosynthesis. $\mathrm{N}$ supplementation improves the expression of small as well as large sub unit of Rubisco [34]. In present study increasing $\mathrm{N}$ supplementation imparted apparent enhancement in pigment synthesis and the photosynthetic efficiency and it was evident that $\mathrm{N}$ supplemented seedlings exhibited less decline due to $\mathrm{NaCl}$ treatment. Salinity stress reduces photosynthetic efficiency through its deleterious effects on the synthesis of chlorophylls and Rubisco protein [19]. Photosynthetic efficiency is corelated with $\mathrm{N}$ and Rubisco concentration and internal $\mathrm{CO}_{2}$ concentrations [35], and in present study higher $\mathrm{N}$ proved much affective in photosynthetic regulation. Further studies are required to unravel the exact mechanisms. $\mathrm{N}$ supplementation significantly increased the content of compatible solutes including proline, glycine betaine, sugars and free amino acids than the control as well as salt stressed counterparts. Increased $\mathrm{N}$ supplementation proved much affective in improving the osmolyte accumulation reflecting in maintenance of growth and hence the amelioration of salinity stress mediated growth retardation. 
In addition of their involvement in the maintenance of tissue water content osmolytes protect major cellular functioning by mediating stress signalling leading to activation of downstream tolerance mechanisms [36-38]. Osmolytes including sugars and amino acids like proline serve as ROS scavengers $[39,40]$. $N$ mediated increased accumulation of compatible solutes prevent oxidative damage induced growth restrictions by protecting the photosynthetic electron transport through ROS elimination and redox homeostasis. Increased accumulation of proline and glycine betaine significantly prevent the salinity induced photosynthetic inhibition [7]. Tissue concentration of compatible solutes is maintained either by irreversible synthesis of the compounds or by a combination of synthesis and degradation, and accumulation of osmolytes is proportional to the external osmolarity [6]. Osmolytes protect the structure and the osmotic balance of cells by maintaining the water influx [37]. Proline, sugars and glycine betaine protect the carboxylase activity of $\mathrm{Ru}$ bisco [41, 42] and hence $N$ supplementation induced increase in their accumulation may have contributed to better photosynthetic efficiency. Martino et al. [43] has demonstrated that accumulated glycine betaine and free amino acids constitute the maximal $\mathrm{N}$ containing osmolytes. Therefore increased $\mathrm{N}$ supplementation prevented the salinity mediated decline in growth of wheat seedlings by improving water content as well as the photosynthetic efficiency. Accumulated osmolytes assist in quick growth recovery after stress release $[1,21,44]$. $\mathrm{N}$ availability significantly improved the antioxidant metabolism by upregulating the activity of key antioxidant enzymes and the contents of non-enzymatic components. $\mathrm{N}$ mediated improved antioxidant potential resulted in alleviation of salinity induced oxidative damage to a significant level. SOD is indespensible for the dismutation of superoxide radicals for preventing the damage to photosynthetic machinery. Increased antioxidant functioning reduces the stress mediated damage to membranes, proteins, nucleic acids and hence maintaining the functional stability $[2,8]$. Earlier it has been reported that increased SOD, CAT and the AsA-GSH functioning prevent the stress triggered oxidative damage [2, 45, 46]. However the reports describing the $\mathrm{N}$ availability induced regulation of antioxidant system are scanty and further studies can be handy in understanding the actual underlying mechanisms. Salinity stress reduces the redox homeostasis thereby hampering the redox dependent cellular functions like electron transport and energy generation [7, 47]. Upregulated AsA-GSH cycle functioning prevents the excess generation of toxic radicals by maintaining the NADP levels in chloroplast. Ascorbic acid, glutathione and tocopherol are the low molecular weight redox buffers and can also interact with numerous other cellular components. In addition of their obvious role in defense, as enzyme cofactors, these redox components regulate growth and development of plants by regulating key processes like mitosis, cell elongation, senescence etc. [47, 48]. Tocopherol preferably neutralizes singlet oxygen in addition of other ROS [48, 49]. Enzymes of AsA-GSH pathway contribute to efficient $\mathrm{H}_{2} \mathrm{O}_{2}$ removal thereby reducing the chances of radical formation through maintainence of redox homeostasis and hence preventing the oxidative damage to key cellular processes like electron transport [50]. N mediated up-regulation of antioxidant system was accompanied by reduced lipoxygenase and protease activity reflecting in greater protection of the lipids and proteins. Stress induced degradation of lipids and proteins decline the structural and functional integrity of cells and $\mathrm{N}$ supplementation assuaged the salinity mediated membrane degradation by preventing the generation of excess ROS. Earlier Ahanger and Agarwal [1, 21] have demonstrated reduced protease activity due to optimal supplementation of $\mathrm{K}$, however reports discussing influence of $\mathrm{N}$ availability are not available. Stresses inflict plant metabolism by inducing protease [1, 21, 44] and lypoxygenase activity [45]. The oxidative signals are crucial for alleviating dormancy and quiescence, triggering cell cycle activation and the genetic as well as epigenetic control underpinning growth and differentiation responses under changing environmental conditions [51]. Redox signalling hub interacts synergistically with phytohormone network for growth regulation and modulations under stress [51, 52]. It was apparent that $\mathrm{N}$ availability imparted beneficial impact on the synthesis of secondary metabolites including phenols and flavonoids. Secondary metabolites including phenols and flavonoids are involved in regulation of auxin transport, photoprotection, mechanical support, seed dispersal and protection against insect herbivory [53]. Plants improve synthesis of flavonoids to protect the stress mediated redox unbalanceinduced changes in metabolism, and in addition are involved in buffering the changes in ROS homeostasis for modulating the ROS-mediated signalling cascade [54]. Secondary metabolites including flavonoids prevent oxidative damage by inhibiting the formation of ROS and protect cellular functioning by scavenging radicals like superoxide [53]. Increased accumulation of phenolic compounds impart greater radical scavenging activity reflecting in apparent growth improvement under stressed conditions [1, 21]. Secondary metabolite compounds like chlorogenic acid, caffeic acid, quercitin and catechin accept electrons in apoplast thereby protecting the cell wall composition and also contribute enormously to the generation of ascorbate pool leading to improved functioning of AsAGSH cycle [49]. PAL is key enzyme regulating the synthesis of secondary metabolites and in present study $\mathrm{N}$ mediated increase in its activity depicts the apparent influence of $\mathrm{N}$ on secondary metabolite accumulation. Non-enzymatic antioxidants neutralize ROS when enzymatic system becomes less efficient. It can be 
inferred from the present findings that increased $\mathrm{N}$ supplementation protected wheat seedlings against salinity mediated oxidative effects by up-regulating antioxidant and osmolyte metabolism, and secondary metabolite accumulation.

\section{Conclusion}

Conclusively, increased $\mathrm{N}$ supplementation protects the growth and metabolism of wheat seedlings through upregulation of the antioxidant system, osmolyte and secondary metabolite accumulation. $\mathrm{N}$ mediated maintenance of the redox homeostasis prevented ill effects of salinity on photosynthetic functioning. $\mathrm{N}$ at both levels proved beneficial in ameliorating the salinity triggered oxidative damage to significant extent. Antioxidant components, both enzymatic and non-enzymatic, increased due to $\mathrm{N}$ supplementation conferring its active involvement in their expression levels. Therefore making it evident that increasing $\mathrm{N}$ supplementation regulates salt tolerance in wheat through modulations in the metabolism of antioxidants, osmolytes and metabolites.

\section{Methods}

\section{Experimental design, plant material and growth} conditions

Wheat (Triticum aestivum L) seeds were procured from College of Agronomy Northwest A\&F University Yangling Shaanxi, China. Seeds were sterilized using 0.01\% $\mathrm{HgCl}_{2}$ followed by thorough washing with distilled water and were sown in bottom perforated pots filled with peat, compost and sand (3:1:1). Soil in pots was supplied with 0,50 and $100 \mathrm{mg} \mathrm{N} \mathrm{kg}^{-1}$ soil in the form of urea. After 10 days of seedlings growth salinity stress was induced by applying $100 \mathrm{mM} \mathrm{NaCl}(100 \mathrm{~mL}$ per pot) on alternate days for 20 days. The native concentration of $\mathrm{N}$, $\mathrm{P}$ and $\mathrm{K}$ in the soil was $65.98,18.78$ and $80.67 \mathrm{mg} \mathrm{kg}^{-1}$ soil respectively with $\mathrm{pH} 7.57$ and water field capacity $52.21 \%$. Pots were arranged in complete randomized block design with five replicates for each treatment and were maintained under green house conditions at the College of Life Science, NorthWest A\&F University Yaangling Shaanxi China. After fourty days of growth seedlings were analyzed for photosynthetic parameters, antioxidant and osmotic constituents, secondary metabolite accumulation and oxidative stress parameters.

\section{Estimation of pigments and photosynthetic parameters}

Total chlorophyll and carotenoids were extracted by macerating fresh leaves in $80 \%$ acetone using pestle and mortar. Absorbance was recorded at 480, 645 and 663 $\mathrm{nm}$ against [55]. Photosynthetic efficiency, intercellular $\mathrm{CO}_{2}$ concentration and stomatal conductance were measured in fully expanded leaf using photosynthesis apparatus Li-6400 (LI-COR Inc., USA).

\section{Determination of leaf water content, soluble sugars, proline and glycine betaine content}

Relative water content (RWC) of leaves was determined by following Smart and Bingham [56]. Content of free sugars [57, 58], free amino acids [59], free proline [60] and glycine betaine [61] were estimated in powdered dry samples in both treated and untreated samples.

\section{Estimation of hydrogen peroxide and superoxide}

For estimation of $\mathrm{H}_{2} \mathrm{O}_{2}, 100 \mathrm{mg}$ fresh leaf tissue was homogenised in $5 \mathrm{~mL}$ of $0.1 \%$ trichloro acetic acid (TCA) and subjected to centrifugation at $10,000 \mathrm{~g}$ for $10 \mathrm{~min}$. $500 \mu \mathrm{L}$ supernatant was mixed with equal volume of potassium phosphate buffer ( $\mathrm{pH}$ 7.0) followed by addition of $1 \mathrm{~mL}$ potassium iodide. After thorough mixing absorbance was recorded at $390 \mathrm{~nm}$ [62].For measurement of $\mathrm{O}_{2}{ }^{-}$ concentrations fresh tissue was homogenized in potassium phosphate buffer $(65 \mathrm{mM}, \mathrm{pH} 7.8)$ and homogenate was centrifuged at $5000 \mathrm{~g}$ for $10 \mathrm{~min}$. Supernatant was mixed with $10 \mathrm{mM}$ hydroxylamine hydrochloride and left for 20 min followed by addition of sulfanilamide and naphthylamine. After $20 \mathrm{~min}$ of incubation at $25^{\circ} \mathrm{C}$ absorbance was measured at $530 \mathrm{~nm}$ [63] and calculations were done using standard curve of $\mathrm{NaNO}_{2}$.

\section{Lipid peroxidation, lipoxygenase and protease activity}

Lipid peroxidation was determined as content of malonaldehyde (MDA) formation. $100 \mathrm{mg}$ fresh leaf tissue was macerated using $1 \%$ TCA followed by centrifugation at $10,000 \mathrm{~g}$ for $5 \mathrm{~min} .1 .0 \mathrm{~mL}$ supernatant was reacted with $0.5 \%$ thiobarbituric acid $(4 \mathrm{~mL})$ at $95^{\circ} \mathrm{C}$ for $30 \mathrm{~min}$ and tubes were subsequently cooled on ice bath followed by centrifugation at $5000 \mathrm{~g}$ for $5 \mathrm{~min}$. Absorbance of supernatant was measured at 532 and $600 \mathrm{~nm}$ [64]. Activity of LOX (EC 1.13.11.12) was estimated according to the method of Doderer et al. [65] and increase in absorbance was recorded at $234 \mathrm{~nm}$ using linoleic acid as substrate. An extinction coefficient of $25 \mathrm{mM}^{-1} \mathrm{~cm}^{-1}$ was for calculation and expressed as units $(1 \mu \mathrm{mol}$ of substrate oxidized $\mathrm{min}^{-1}$ ) $\mathrm{mg}^{-1}$ protein. Protease (EC 3.4.21.40) activity was assayed by homogenizing fresh tissue in chilled $50 \mathrm{mM}$ sodium potassium buffer $(\mathrm{pH}$ 7.4) containing $1 \%$ PVP and the homogenate centrifuged at $5000 \mathrm{~g}$ for $5 \mathrm{~min}$ at $4{ }^{\circ} \mathrm{C}$. Tyrosine released was read at $660 \mathrm{~nm}$ after incubating $1 \mathrm{~mL}$ supernatant with casein at $40^{\circ} \mathrm{C}$ and reacting the mixture with Folin Ciocalteu's reagent in alkaline medium. Activity was expressed as $\mu \mathrm{g}$ tyrosine released $\mathrm{mg}^{-1}$ protein [66].

\section{Determination of nitrate Reductase}

For assaying nitrate reductase (NR) activity $300 \mathrm{mg}$ fresh leaf tissue was incubated in $100 \mathrm{mM}$ potassium phosphate buffer (pH 7.5) containing $200 \mathrm{mM} \mathrm{KNO}_{3}$ and $0.5 \%$ n-propanol $(\mathrm{v} / \mathrm{v})$ at $30^{\circ} \mathrm{C}$ for $3 \mathrm{~h}$ in dark. 
Thereafter, aliquot $(1 \mathrm{~mL})$ was mixed with equal volume of $1 \%$ sulphanilamide and $0.2 \%$ 1-nephthylethylene diamine dihydrochloride, and mixture was allowed to stand for $20 \mathrm{~min}$. Thereafter the absorbance was recorded at $540 \mathrm{~nm}$ [67].

\section{Assay of antioxidant enzymes}

For extraction of antioxidant enzymes fresh $5.0 \mathrm{~g}$ leaf tissue was homogenised in pre-chilled pestle and mortar using phosphate buffer (100 mM, pH 7.8) containing 1\% polyvinyl pyrolidine and $1 \mathrm{mM}$ EDTA. The homogenate was centrifuged at $12,000 \mathrm{~g}$ for $15 \mathrm{~min}$ at $4{ }^{\circ} \mathrm{C}$. For ascorbate peroxidase (APX) extraction buffer was supplemented with $2 \mathrm{mM}$ ascorbate. Supernatant was used as enzyme source. Activity of superoxide dismutase (SOD, EC 1.15.1.1) was assayed by monitoring the ability of enzyme to inhibit the photochemical reduction of nitroblue tetrazolium chloride (NBT) at $560 \mathrm{~nm}$ [68] Assay mixture was incubated under florescent light for $15 \mathrm{~min}$ and the absorbance was recorded against the nonilluminated blank and activity expressed as EU $\mathrm{mg}^{-1}$ protein. Catalase (EC 1.11.1.6) activity was assayed following Aebi [69] and change in absorbance was monitored at $240 \mathrm{~nm}$ for $2 \mathrm{~min}$ in an assay mixture containing $50 \mathrm{mM}$ potassium phosphate buffer ( $\mathrm{pH} 7.0$ ), $\mathrm{H}_{2} \mathrm{O}_{2}$ and $100 \mu \mathrm{L}$ enzyme extract. Extinction coefficient of $0.036 \mathrm{mM}^{-1} \mathrm{~cm}^{-1}$ was used for calculation. Ascorbate peroxidase (APX, EC 1.11.1.11) was assayed by following method of Nakano and Asada [70] and disappearance of $\mathrm{H}_{2} \mathrm{O}_{2}$ was monitored as decrease in absorbance at 290 $\mathrm{nm}$ for $3 \mathrm{~min}$. An extinction coefficient of $2.8 \mathrm{mM}^{-1}$ $\mathrm{cm}^{-1}$ was used for calculation and activity was expressed as $\mathrm{EU} \mathrm{mg^{-1 }}$ protein. For estimation of glutathione reductase (GR; EC 1.6.4.2) activity glutathione dependent oxidation of NADPH was monitored as change in absorbance at $340 \mathrm{~nm}$ for $2 \mathrm{~min}$ [71]. Activity was expressed as $\mathrm{EU} \mathrm{mg} \mathrm{m}^{-1}$ protein and extinction coefficient of $6.2 \mathrm{mM}^{-1} \mathrm{~cm}^{-1}$ was used for calculation. Activity of MDHAR (EC: 1.6.5.4) was assayed in a reaction mixture containing Tris- $\mathrm{HCl}$ buffer $(50 \mathrm{mM}, \mathrm{pH} 7.5), 200 \mu \mathrm{M}$ $\mathrm{NADPH}, 250 \mu \mathrm{M}$ AsA and enzyme. Absorbance was read at $340 \mathrm{~nm}$ for $2 \mathrm{~min}$ [72] and extinction coefficient of $6.2 \mathrm{mM}^{-1} \mathrm{~cm}^{-1}$ was used for calculation. Activity of DHAR (EC: 1.8.5.1) was measured following Nakano and Asada [70] in assay mixture containing $50 \mathrm{mM}$ potassium phosphate buffer (pH 7.0), GSH $(2.5 \mathrm{mM})$, and $100 \mu \mathrm{M}$ DHA. Change in optical density was read at 265 $\mathrm{nm}$ for $2 \mathrm{~min}$ and extinction coefficient of $14 \mathrm{mM}^{-1} \mathrm{~cm}^{-1}$ was used for calculation.

\section{Estimation of ascorbate, reduced glutathione, and tocopherol}

Ascorbate (AsA) content was determined by macerating fresh plant material in 6\% TCA and supernatant was mixed with $2 \%$ dinitrophenylhydrazine and $10 \%$ thiourea. After incubating in water bath for $15 \mathrm{~min}$ samples were cooled and $5 \mathrm{~mL}$ of cooled $80 \% \mathrm{H}_{2} \mathrm{SO}_{4}$ was added. Absorbance was taken at $530 \mathrm{~nm}$ [73]. Standard curve of AsA was used for calculation. Estimation of reduced glutathione (GSH) was carried by following method described by Ellman [74]. $100 \mathrm{mg}$ fresh tissue was homogenised in phosphate buffer ( $\mathrm{pH} 8.0$ ) and $500 \mu \mathrm{L}$ supernatant was mixed with 5, 5-dithiobis-2-nitrobenzoic acid. Optical density was read at $412 \mathrm{~nm}$ and concentration of GSH was determined from standard graph of GSH. Tocopherol was extracted in ethanol and petroleum ether (1.6:2). After centrifugation supernatant was incubated with $2 \%$ of 2,2 dipyridyl in dark followed by addition o distilled water (4 $\mathrm{mL}$ ). Absorbance was recorded at $520 \mathrm{~nm}$ [75] and standard curve was used for calculation.

\section{Estimation of total phenols, flavonoids and assay of phenylalanine ammonia lyase}

Total phenols and flavonoids were estimated by following the method of Malick and Singh [76] and Zhishen et al. [77]. Phenylalanine ammonia lyase (PAL) was assayed following Zucker [78] and formation of transcinnamic acid was measured at $290 \mathrm{~nm}$.

\section{Estimation of $\mathrm{Na}, \mathrm{K}$ and $\mathrm{N}$}

$\mathrm{Na}$ and $\mathrm{K}$ were estimated flame photometrically described by Ahanger et al. [79]. Micro-Kzeldahl's method suggested by Jackson [80] and modified by Iswaran and Marwaha [81] was employed for estimation of $\mathrm{N}$ content.

\section{Statistical analysis}

Data is mean $( \pm \mathrm{SE})$ of three replicates and for testing significance of data Duncan's Multiple Range Test was performed using One Way ANOVA and least significant difference (LSD) was calculated at $p<0.05$.

\section{Acknowledgements \\ Authors are thankful to College of Life Sciences, Northwest A\&F University, Yangling, Shaanxi for proving research facilities and funding the research group. First author (MAA) is highly thankful to Northwest A\&F University Yangling Shaanxi for Post Doctoral Research Fellowship. Research in lab of Prof Zhang is funded by National Key Research and Development Program of China (No. 2017YFE0114000). MAES and AAA extend their appreciation to the Researchers Supporting Project Number (RSP-2019/86), King Saud University, Riyadh, Saudi Arabia.}

\section{Authors' contributions}

MAA and LZ designed the experiments. MAA, CQ, XXD and QM carried out experiments. MAA, CQ, NB and MEE wrote and revised the manuscript. MAA, NB and MAES collected literature. MAES and AAA conducted statistical analysis and formating. All authors have read and approved the final manuscript. 


\section{Availability of data and materials}

All data generated or analysed during this study are included in this published article.

\section{Ethics approval and consent to participate}

Not applicable.

\section{Consent for publication}

Not applicable.

\section{Competing interests}

The authors declare that they have no competing interests.

\section{Author details}

${ }^{1}$ College of Life Sciences, Northwest A\&F University, Yangling, Shaanxi, China. ${ }^{2}$ Botany Department, Faculty of Science, Tanta University, Tanta, Egypt. ${ }^{3}$ Sainsbury Laboratory, University of Cambridge, Cambridge, UK. ${ }^{4}$ Botany and Microbiology Department, College of Science, King Saud University, Riyadh 11451, Saudi Arabia. ${ }^{5}$ Botany Department, Faculty of Science, Damanhour University, Damanhour, Egypt.

Received: 14 April 2019 Accepted: 20 October 2019

Published online: 08 November 2019

\section{References}

1. Ahanger MA, Agarwal RM. Salinity stress induced alterations in antioxidant metabolism and nitrogen assimilation in wheat (Triticum aestivum L) as influenced by potassium supplementation. Plant Physiol Biochem. 2017;115: 449-60.

2. Ahmad P, Ahanger MA, Alam P, Alyemeni MN, Wijaya L, Ali S, Ashraf M. Silicon (Si) supplementation alleviates $\mathrm{NaCl}$ toxicity in mung bean [Vigna radiata (L.) wilczek] through the modifications of physio-biochemical attributes and key antioxidant enzymes. J Plant Growth Regul. 2019;38(1): 70-82.

3. Fatma M, Masood A, Per TS, Khan NA. Nitric Oxide Alleviates Salt Stress Inhibited Photosynthetic Performance by Interacting with Sulfur Assimilation in Mustard. Front Plant Sci. 2016;25:521. https://doi.org/10.3389/ fpls.2016.00521.

4. Parida AK, Das AB. Salt tolerance and salinity effects on plants: a review. Ecotox Environ Safety. 2005;60(3):324-49.

5. Negrao S, Schmöckel SM, Tester M. Evaluating physiological responses of plants to salinity stress. Ann Bot. 2017;119(1):1-11.

6. Gupta B, Huang B. Mechanism of salinity tolerance in plants: physiological, biochemical, and molecular characterization. Int J Genomics. 2014;2014: 701596. https://doi.org/10.1155/2014/701596.

7. Khan MIR, Asgher M, Khan NA. Alleviation of salt-induced photosynthesis and growth inhibition by salicylic acid involves glycine betaine and ethylene in mungbean (Vigna radiata L.). Plant Physiol Biochem. 2014;80:67-74.

8. Ahmad P, Jaleel CA, Salem MA, Nabi G, Sharma S. Roles of enzymatic and non-enzymatic antioxidants in plants during abiotic stress. Crit Rev Biotechnol. 2010:30:161-75.

9. Guo R, Shi LX, Yan C, Zhong X, Gu FX, Liu Q, Xia X, Li H. lonomic and metabolic responses to neutral salt or alkaline salt stresses in maize (Zea mays L.) seedlings. BMC Plant Biol. 2017;17:41. https://doi.org/10.1186/ s12870-017-0994-6.

10. Deinlein U, Stephan AB, Horie T, Luo W, Xu G, Schroeder Jl. Plant salttolerance mechanisms. Trends Plant Sci. 2014;19(6):371-9.

11. Hauser F, Horie T. A conserved primary salt tolerance mechanism mediated by HKT transporters: a mechanism for sodium exclusion and maintenance of high $\mathrm{K}^{+} / \mathrm{Na}^{+}$ratio in leaves during salinity stress. Plant Cell Environ. 2010; 33:552-65.

12. Ahanger MA, Tomar NS, Tittal M, Argal S, Agarwal RM. Plant growth under water/ salt stress: ROS production; antioxidants and significance of added potassium under such conditions. Physiol Mol Biol Plants. 2017;23(4):731-44.

13. Couee I, Sulmon C, Gouesbet G, El Amrani A. An involvement of soluble sugars in reactive oxygen species balance and responses to oxidative stress in plants. J Exp Bot. 2006;57:449-59.

14. Shangguan Z, Shao M, Dyckmans J. Effects of nitrogen nutrition and water deficit on net photosynthetic rate and chlorophyll fluorescence in winter wheat. J Plant Physiol. 2000;156:46-51.
15. Vanacker $H$, Sandalio LM, Jimenez A, Palma JM, Corpas FJ, Meseguer V, Gomez M, Sevilla F, Leterrier M, Foyer CH, del Rio LA. Roles for redox regulation in leaf senescence of pea plants grown on different sources of nitrogen nutrition. J Exp Bot. 2006;57(8):1735-45.

16. Martinez-Andujar C, Ghanem ME, Albacete A, Perez-Alfocea F. Response to nitrate/ammonium nutrition of tomato (Solanum lycopersicum L.) plants over-expressing a prokaryotic $\mathrm{NH}_{4}{ }^{+}$-dependent asparagine synthetase. J Plant Physiol. 2013;170:676-87.

17. Tewari RK, Kumar P, Sharma PN. Oxidative stress and antioxidant responses in young leaves of mulberry plants grown under nitrogen, phosphorus or potassium deficiency. J Integr Plant Biol. 2007;49(3):313-22.

18. Chokshi K, Pancha I, Ghosh A, Mishra S. Nitrogen starvation-induced cellular crosstalk of ROS-scavenging antioxidants and phytohormone enhanced the biofuel potential of green microalga Acutodesmus Dimorphus. Biotechnol Biofuels. 2017;10:60. https://doi.org/10.1186/s13068-017-0747-7.

19. Iqbal N, Umar S, Khan NA. Nitrogen availability regulates proline and ethylene production and alleviates salinity stress in mustard (Brassica juncea). J Plant Physiol. 2015;178:84-91.

20. Giorgi A, Mingozzi M, Madeo M, Speranza G, Cocucci M. 2009. Effect of nitrogen starvation on the phenolic metabolism and antioxidant properties of yarrow (Achillea collina Becker ex Rchb.). Food Chem. 2009;114:204-11.

21. Ahanger MA, Agarwal RM. Potassium improves antioxidant metabolism and alleviates growth inhibition under water and osmotic stress in wheat (Triticum aestivum L). Protoplasma. 2017;254(4):1471-86.

22. Pan YJ, Liu L, Lin YC, Zu YG, Li LP, Tang ZH. Ethylene antagonizes salt-induced growth retardation and cell death process via transcriptional controlling of ethylene-, BAG- and senescence-associated genes in Arabidopsis. Front Plant Sci. 2016;7:696. https://doi.org/10.3389/fpls.2016.00696.

23. Ahanger MA, Alyemeni MN, Wijaya L, Alamri SA, Alam P, Ashraf M, Ahmad P. Potential of exogenously sourced kinetin in protecting Solanum lycopersicum from $\mathrm{NaCl}$-induced oxidative stress through up-regulation of the antioxidant system, ascorbate-glutathione cycle and glyoxalase system. PLoS One. 2018; 13(9):e0202175. https://doi.org/10.1371/journal. pone.0202175.

24. James RA, Davenport RJ, Munns R. Physiological characterization of two genes for $\mathrm{Na}^{+}$exclusion in durum wheat, Nax1 and Nax2. Plant Physiol. 2006;142:1537-47.

25. Shabala S, Cuin TA. Potassium transport and plant salt tolerance. Physiol Plant. 2008:133:651-69.

26. Jiang C, Belfield EJ, Mithani A, Visscher A, Ragoussis J, Mott R, JAC S, Harberd NP. ROS-mediated vascular homeostatic control of root-to-shoot soil Na delivery in Arabidopsis. EMBO J. 2012;31:4359-70.

27. Ahanger MA, Tittal M, Mir RA, Agarwal RM. Alleviation of water and osmotic stress-induced changes in nitrogen metabolizing enzymes in Triticum aestivum L. cultivars by potassium. Protoplasma. 2017;254(5):1953-63.

28. Roggatz U, McDonald AJS, Stadenberg I, Schurr U. Effects of nitrogen deprivation on cell division and expansion in leaves of Ricinus communis $L$. Plant Cell Environ. 1999;22(1):81-9.

29. Juppner J, Mubeen U, Leisse A, Caldana C, Wiszniewski A, Steinhauser D, Giavalisco $P$. The target of rapamycin kinase affects biomass accumulation and cell cycle progression by altering carbon/nitrogen balance in synchronized Chlamydomonas reinhardtii cells. Plant J. 2018;93(2):355-76.

30. Keisham M, Mukherjee S, Bhatla SC. Mechanisms of sodium transport in plants-progresses and challenges. Int J Mol Sci. 2018;19(3):647. https://doi. org/10.3390/ijms19030647.

31. Zeng Y, Li Q, Wang H, Zhang J, Du J, Feng H, Blumwald E, Yu L, Xu G. Two $\mathrm{NHX}$-type transporters from Helianthus tuberosus improve the tolerance of rice to salinity and nutrient deficiency stress. Plant Biotechnol J. 2018;16(1):310-21.

32. Agarwal RM, Tomar NS, Jatav KS, Sharma GL. Potassium induced changes in flowering plants. In: Flower Retrospect and Prospect (Professsor Vishwambhar Puri Birth Centenary Volume). Delhi: SR Scientific Publication; 2009. p. $158-86$.

33. Heckathorn SA, Poeller GJ, Coleman JS, Hallberg RL. Nitrogen availability and vegetative development influence the response of ribulose 1,5bisphosphate carboxylase/oxygenase, phosphoenolpyruvate carboxylase, and heat-shock protein content to heat stress in Zea mays L. Int J Plant Sci. 1996;157(5):546-53.

34. Imai K, Suzuki Y, Mae T, Makino A. 2008. Changes in the synthesis of Rubisco in Rice leaves in relation to senescence and N influx. Ann Bot. 2008; 101(1):135-44

35. Makino A. Rubisco and nitrogen relationships in rice: leaf photosynthesis and plant growth. Soil Sc Plant Nut. 2003;49(3):319-27. 
36. Eveland $A L$, Jackson DP. Sugars, signalling, and plant development. J Exp Bot. 2012;63(9):3367-77. https://doi.org/10.1093/jxb/err379.

37. Ahanger MA, Tyagi SR, Wani MR, Ahmad P. Drought Tolerance: Role of Organic Osmolytes, Growth Regulators and Mineral Nutrients. In "Physiological Mechanisms and Adaptation Strategies in Plants under Changing Environment" 1. Ahmad P, Wani MR. New York: Springer Science+ Business Media, Inc. 2014;25-56.

38. Smeekens $\mathrm{S}$, Hellmann HA. Sugar sensing and signaling in plants. Front Plant Sci. 2014;5:113.26. https://doi.org/10.3389/fpls.2014.00113.

39. Hayat S, Hayat Q, Alyemeni MN, Wani AS, Pichtel J, Ahmad A. Role of proline under changing environments: a review. Plant Signal Behav. 2012;7: $1456-66$.

40. Keunen E, Peshev D, Vangronsveld J, Ende WVD, Cuypers A. Plant sugars are crucial players in the oxidative challenge during abiotic stress: extending the traditional concept. Plant Cell Environ. 2013:36:1242-55.

41. Sivakumar P, Sharmila P, Saradhi PP. Proline alleviates salt-stress-induced enhancement in Ribulose-1,5-Bisphosphate Oxygenase activity. Biochem Biophys Res Commun. 2000;279(2):512-5.

42. Sivakumar P, Harmila P, Jain V, Saradhi PP. Sugars have potential to curtail oxygenase activity of Rubisco. Biochem Biophys Res Commun. 2002;298(2): 247-50.

43. Martino CD, Delfine S, Pizzuto R, Loreto F. Free amino acids and glycine betaine in leaf osmoregulation of spinach responding to increasing salt stress. New Phytol. 2003;158(3):455-63.

44. Pandey R, Agarwal RM, Jeevaratnam K, Sharma GL. Osmotic stress induced alterations in rice (Oryza sativa $\mathrm{L}$ ) and recovery on stress release. Plant Growth Regul. 2004;42:79-87.

45. Nahar K, Hasanuzzaman M, Rahman A, Alam MM, Mahmud JA, Suzuki T, Fujita M. Polyamines confer salt tolerance in mung bean (Vigna radiata L.) by reducing sodium uptake, improving nutrient homeostasis, antioxidant defense, and methylglyoxal detoxification systems. Front. Plant Sci. 2016;7: 1104. https://doi.org/10.3389/fpls.2016.01104.

46. Nahar K, Hasanuzzaman M, Suzuki T, Fujita M. Polyamines-induced aluminum tolerance in mung bean: a study on antioxidant defense and methylglyoxal detoxification systems. Ecotoxicology. 2017;26(1):58-73.

47. Anjum NA, Gill R, Kaushik M, Hasanuzzaman M, Pereira E, Ahmad I, Tuteja N, Gill SS. ATP-sulfurylase, sulfur-compounds, and plant stress tolerance. Front Plant Sci. 2015;6:210. https://doi.org/10.3389/fpls.2015.00210.

48. Tokunaga T, Miyahara K, Tabata K, Esaka M. Generation and properties of ascorbic acid-overproducing transgenic tobacco cells expressing sense RNA for I-galactono-1,4-lactone dehydrogenase. Planta. 2005;220(6):854-63.

49. Foyer $\mathrm{CH}$, Noctor $\mathrm{G}$. Redox homeostasis and antioxidant signaling: a metabolic interface between stress perception and physiological responses. Plant Cell. 2005;17(7):1866-75.

50. Foyer $\mathrm{CH}$, Trebst A, Noctor G. Protective and signalling functions of ascorbate, glutathione and tocopherol in chloroplasts. In Advances in photosynthesis and respiration: Photoprotection, Photoinhibition, Gene Regulation, and Environment, 19, B. Demmig-Adams, W.W. Adams, (Dordrecht: Springer Science Publishers). 2005;241-268.

51. Considine MJ, Foyer $\mathrm{CH}$. Redox regulation of plant development. Antioxid Redox Signal. 2014;21(9):1305-26.

52. Schippers $\mathrm{JH}$, Foyer $\mathrm{CH}$, van Dongen JT. Redox regulation in shoot growth, SAM maintenance and flowering. Curr Opin Plant Biol. 2016;29:121-8.

53. Commisso M, Toffali K, Strazzer P, Stocchero M, Ceoldo S, Baldan B, Levi M, Guzzo F. Impact of Phenylpropanoid compounds on heat stress tolerance in carrot cell cultures. Front Plant Sci. 2016;7:1439. https://doi.org/10.3389/ fpls.2016.01439.

54. Brunetti C, Fini A, Sebastiani F, Gori A, Tattini M. Modulation of phytohormone signaling: a primary function of flavonoids in plantenvironment interactions. Front Plant Sci. 2018;9:1042. https://doi.org/10 3389/fpls.2018.01042

55. Arnon DI. Copper enzymes in isolated chloroplast polyphenol oxidase in Beta vulgaris. Plant Physiol. 1949;24:1-15.

56. Smart RE, Bihgham GE. Rapid estimates of relative water content. Plant Physiol. 1974;53:258-60.

57. Fong J, Schaffer FL, Kirk PL. The ultramicrodetermination of glycogen in liver. A comparison of the anthrone and reducing-sugar methods. Arch Biochem Biophys. 1953;45(2):319-26.

58. Jain VK, Guruprasad KN. Effect of chlorocholin chloride and gibberellic acid on the anthocyanin synthesis in radish seedlings. Plant Physiol. 1989;75:233-6.
59. Sadasivam S, Manickam A. Biochemical methods. 2nd ed. New Delhi: New Age International Limited Publishers; 2004.

60. Bates LS, Waldre RP, Teare ID. Rapid determination of free proline for water stress studies. Plant Sci. 1973;39:205-7.

61. Grieve CM, Grattan SR. Rapid assay for determination of water soluble quaternary ammonium compounds. Plant Soil. 1983;70:303-7.

62. Velikova V, Yordanov I, Edreva A. Oxidative stress and some antioxidant systems in acid rain treated bean plants, protective role of exogenous polyamines. Plant Sci. 2000;151:59-66.

63. Yang $H$, Wu F, Cheng J. Reduced chilling injury in cucumber by nitric oxide and the antioxidant response. Food Chem. 2011;127:1237-42.

64. Heath RL, Packer L. Photoperoxidation in isolated chloroplasts: I. Kinetics and stoichiometry of fatty acid peroxidation. Arch Biochem Biophys. 1968; 125:189-98.

65. Doderer A, Kokkelink I, van der Veen S, Valk B, Schram A, Douma A. Purification and characterization of two lipoxygenase isoenzymes from germinating barley. Biochim Biophys Acta. 1992;112:97-104.

66. Green NM, Neurath H. Proteolytic enzymes. In: Neurath H, Vailey K, editors. The Proteins, vol. II. New York: Part B, Academic Press; 1954. p. 1057-198.

67. Srivastava HS. In vivo activity of nitrate reductase in maize seedlings. Indian J Biochem Biophys. 1974;11:230-2.

68. Bayer WF, Fridovich JL. Assaying for superoxide dismutase activity: some large consequences of minor changes in conditions. Anal Biochem. 1987; 161:559-66.

69. Aebi H. Catalase in vitro. Methods Enzymol. 1984;105:121-6.

70. Nakano Y, Asada K. Hydrogen peroxide is scavenged by ascorbate-specific peroxidase in spinach chloroplasts. Plant Cell Physiol. 1981;22:867-80.

71. Foyer $\mathrm{CH}$, Halliwell B. The presence of glutathione and glutathione reductase in chloroplast: a proposed role in ascorbic acid metabolism. Planta. 1976;133:21-5.

72. Hossain MA, Nakano Y, Asada K. Monodehydroascorbate reductase in spinach chloroplasts and its participation in the regeneration of ascorbate for scavenging hydrogen peroxide. Plant Cell Physiol. 1984;25:385-95.

73. Mukherjee SP, Choudhuri MA. Implications of water stress-induced changes in the levels of endogenous ascorbic acid and hydrogen peroxide in Vigna seedlings. Physiol Plant. 1983;58:166-70.

74. Ellman GL. Tissue sulphydryl groups. Arch Biochem Biophys. 1959;82:70-7.

75. Backer H, Frank O, de Angells B, Feingold S. Plasma tocopherol in man at various times after ingesting free or ocetylaned tocopherol. Nutr Rep Int. 1980;21:531-6.

76. Malick CP, Singh MB. Plant enzymology and histoenzymology. New Delhi: Kalyani Publishers; 1980. p. 286.

77. Zhishen J, Mengcheng T, Jianming W. The determination of flavonoid contents in mulberry and their scavenging effects on superoxide radicals. Food Chem. 1999;64:555-9.

78. Zucker M. Induction of phenylalanine deaminase by light and its relation to chlorogenic acid synthesis in potato tuber tissue. Plant Physiol. 1965;40:779-84.

79. Ahanger MA, Agarwal RM, Tomar NS, Shrivastava M. Potassium induces positive changes in nitrogen metabolism and antioxidant system of oat (Avena sativa L cultivar Kent). J Plant Interact. 2015;10(1):211-23.

80. Jackson ML. Soil chemical analysis. New Delhi: Prentice Hall of India Pvt Ltd; 1973.

81. Iswaran V, Marwaha TS. A modified rapid kjeldahl method for determination of total nitrogen in agricultural and biological materials. Geobios. 1980;7:281e282.

\section{Publisher's Note}

Springer Nature remains neutral with regard to jurisdictional claims in published maps and institutional affiliations. 